Published in final edited form as:

Cardiovasc Drugs Ther. 2014 April ; 28(2): 115-122. doi:10.1007/s10557-013-6502-9.

\title{
Memory T Cells Mediate Cardiac Allograft Vasculopathy and are Inactivated by Anti-OX40L Monoclonal Antibody
}

\section{Hao Wang,}

Department of General Surgery, Tianjin Medical University General Hospital, Tianjin General Surgery Institute, Tianjin, China

\section{Zhixiang Zhang,}

Department of General Surgery, Tianjin Medical University General Hospital, Tianjin General Surgery Institute, Tianjin, China

\section{Weijun Tian,}

Department of General Surgery, Tianjin Medical University General Hospital, Tianjin General Surgery Institute, Tianjin, China

\section{Tong Liu,}

Department of General Surgery, Tianjin Medical University General Hospital, Tianjin General Surgery Institute, Tianjin, China

\section{Hongqiu Han,}

Department of General Surgery, Tianjin Medical University General Hospital, Tianjin General Surgery Institute, Tianjin, China

\section{Bertha Garcia,}

Department of Pathology, The University of Western Ontario, London, Ontario, Canada

Xian C. Li, and

Department of Medicine, Harvard Medical School, Boston, MA, USA

\section{Caigan Du}

Department of Urologic Sciences, The University of British Columbia, Vancouver, British Columbia, Canada

\section{Abstract}

\begin{abstract}
Purpose-Cardiac allograft vasculopathy (CAV) is a major complication limiting the long-term survival of cardiac transplants. The role of memory $\mathrm{T}$ cells $\left(\mathrm{T}_{\mathrm{mem}}\right)$ in the pathogenesis of CAV remains elusive. This study investigated the role of $\mathrm{T}_{\mathrm{mem}}$ cells in the development of CAV and the therapeutic potential of targeting the OX40/OX40L pathway for heart transplant survival.
\end{abstract}

Methods- $\mathrm{T}_{\text {mem }}$ cells were generated in Rag- $1^{-/-}$C57BL/6 (B6) mice by homeostatic proliferation (HP) of CD40L null CD $3^{+} \mathrm{T}$ cells from B6 mice. Rag- ${ }^{-1-} \mathrm{B} 6$ mice $\left(\mathrm{H}-2^{\mathrm{b}}\right)$ harboring

hwangca272@gmail.com, caigan@mail.ubc.ca.

Conflict of Interest None of the authors have any conflicts of interest. 
$\mathrm{T}_{\text {mem }}$ cells received cardiac allografts from $\mathrm{BALB} / \mathrm{c}$ mice $\left(\mathrm{H}-2^{\mathrm{d}}\right)$, and were either untreated or treated with anti-OX40L monoclonal antibody $(\mathrm{mAb})(0.5 \mathrm{mg} / \mathrm{mouse} /$ day $)$ for 10 days.

Results-Six weeks after HP, the majority of transferred CD40L ${ }^{-/-} \mathrm{T}$ cells in Rag- $1^{-/-} \mathrm{B} 6$ mice were differentiated to CD44 $4^{\text {high }}$ and CD62 $\mathrm{L}^{\text {low }} \mathrm{T}_{\text {mem }}$ cells. BALB/c heart allografts in Rag- $1^{-/-}$ B6 recipient mice in the presence of these $\mathrm{T}_{\text {mem }}$ cells developed a typical pathological feature of CAV; intimal thickening, 100 days after transplantation. However, functionally blocking the OX40/OX40L pathway with anti-OX40L mAb significantly prevented CAV development and reduced the $\mathrm{T}_{\mathrm{mem}}$ cell population in recipient mice. Anti-OX40L mAb therapy also significantly decreased cellular infiltration and cytokine (IFN- $\gamma$, TNF- $\alpha$ and TGF- $\beta$ ) expression in heart allografts.

Conclusions $-\mathrm{T}_{\text {mem }}$ cells mediate $\mathrm{CAV}$ in heart transplants. Functionally blocking the OX40/ OX40L pathway using anti-OX40L mAb therapy prevents $\mathrm{T}_{\text {mem }}$ cell-mediated CAV, suggesting therapeutic potential for disrupting OX40-OX40L signaling in order to prevent CAV in heart transplant patients.

\section{Keywords}

Heart transplantation; Cardiac allograft vasculopathy; Memory Tcell; OX40 pathway; AntiOX40L antibody therapy

\section{Introduction}

Heart transplantation is the most effective therapy for end-stage heart failure or severe coronary artery disease [1]; however, the survival of heart transplants still remains a significant clinical challenge. It has been suggested that chronic rejection or cardiac allograft vasculopathy (CAV) of heart transplants contributes to $30 \%$ of deaths at 5 years following cardiac transplantation [2]. CAV is defined as a type of arteriosclerosis, characterized by concentric intimal hyperplasia with luminal narrowing from distal small vessels to all of the intramyocardial and epicardial arteries of the allograft [3-5]. To date, there is no effective treatment available for the prevention or treatment of CAV [6].

Memory $\mathrm{T}\left(\mathrm{T}_{\mathrm{mem}}\right)$ cells are a subpopulation of activated $\mathrm{T}$ cells that persist after the initial $\mathrm{T}$ cell response. Typically, after such a response and in the absence of antigen stimulation, the majority of $\mathrm{T}$ cells die off, either to prevent further damage to the tissue or to make space for future $\mathrm{T}$ cells, but $\mathrm{T}_{\mathrm{mem}}$ cells survive and provide continual immune protection to the host [7]. Early studies have shown that in coronary arteries from patients with CAV, most infiltrating $\mathrm{T}$ cells express the phenotype of $\mathrm{T}_{\text {mem }}$ cells $[8,9]$, suggesting that this subtype of T cells may play an important role in the development of CAV [10]. However, this hypothesis has not yet been tested.

OX40 (CD134), initially viewed as a T-cell activation marker [11], is a member of the tumor necrosis factor receptor (TNFR) superfamily [12]. OX40 expression has also been observed in other types of leukocytes, such as regulatory $\mathrm{T}$ (Treg) cells [13], natural killer T (NKT) cells [14], natural killer (NK) cells [15], and neutrophils [16]. The ligand of OX40 (OX40L, CD252) is a member of the TNF superfamily [12] and can be found on dendritic cells (DCs), B cells, and inflamed vascular endothelial cells [17]. It has been suggested that OX40- 
OX40L interaction is one of key pathways for activation of multiple cellular components in the immune response and is becoming an emerging target for immunosuppression [18]. In addition to its stimulatory function in effector T cells, the OX40-OX40L signaling pathway has been found to play a key role in the survival and homeostasis of $T_{\text {mem }}$ cells [19-21], which has been supported by the fact that treatments with anti-OX40 agonists result in higher production of $\mathrm{T}_{\text {mem }}$ cells $[19,22,23]$, whereas blocking OX40 signaling during the secondary exposure completely suppresses $T_{\text {mem }}$ cell expansion [23]. The objective of this study is to investigate the role of $\mathrm{T}_{\text {mem }}$ cells in CAV development, and to test the therapeutic potential of disrupting OX40-OX40L interaction in the prevention of CAV in a murine model.

To investigate the activities of $\mathrm{T}_{\text {mem }}$ cells in the pathogenesis of CAV, we used a murine model of CAV that is mediated by CD40L deficient $\mathrm{T}_{\text {mem }}$ cells. We generated CD40L deficient $\mathrm{T}_{\text {mem }}$ cells by the homeostatic proliferation (HP) of naïve $\mathrm{CD} 40 \mathrm{~L}^{-/-} \mathrm{T}$ cells in Rag- $1^{-/-}$mice that do not have mature lymphocytes ( $\mathrm{T}$ and $\mathrm{B}$ cells) [24]. The rationale for this experimental model being; firstly, induction therapy using a lymphocyte-depleting agent, such as alemtuzumab or rabbit anti-thymocyte globulin, expands CD4 $\mathrm{T}_{\text {mem }}$ cells that predominate during acute rejection episodes in patients [25], which may be due to the fact that compared with naïve $\mathrm{T}$ cells, $\mathrm{T}_{\text {mem }}$ cells are more difficult to deplete, presumably because of their survival advantages over naïve $T$ cells [26], and are likely to have faster kinetics of HP after lymphoablation [27]. The HP of naïve T cells in an "empty" host also results in the generation of $\mathrm{T}_{\text {mem }}$ cells $[28,29]$. Secondly, cardiac allografts in mice can survive for 100 days in CD40L deficient recipients, but develop CAV [30], and in sensitized recipients, CD40-CD40L interaction is absent or not required for the activation of $\mathrm{T}_{\mathrm{mem}}$ cells that mediate allograft rejection [31,32].

\section{Materials and Methods}

Animals

Male adult BALB/c (10-12 week old, H-2 ${ }^{\mathrm{d}}$ ) or Rag- $1^{-/}$C57BL/6 (B6) mice (10-12 weeks old, $\mathrm{H}-2^{\mathrm{b}}$ ) (Jackson Laboratories, Bar Harbor, MA, USA) were used as donors or recipients respectively. CD40L ${ }^{-1-}$ B6 mice (10-12 weeks old) (Jackson Laboratories) were used as a donor of naïve $\mathrm{CD}^{+} \mathrm{T}$ cells for generating $\mathrm{T}_{\text {mem }}$ cells in Rag-1 $1^{-/}$B6 mice by HP. Animals were housed in the Animal Care Facility of the University of Western Ontario (London, ON) and handled following the protocol approved by the animal research ethical review board of the University of Western Ontario according to the Canadian Council on Animal Care guidelines [33].

\section{Adoptive Transfer of Purified T Cells and $\mathrm{T}_{\text {mem }}$ Phenotype Analysis}

To establish a recipient model harboring $\mathrm{CD} 40 \mathrm{~L}^{-/-} \mathrm{T}_{\text {mem }}$ by HP in Rag- $1^{-/-} \mathrm{B} 6$ mice, $\mathrm{CD}^{+}$ T cells were isolated using CD3-positive selection-MACS ${ }^{\circledR}$ Technology (Miltenyi Biotec Inc., Auburn, CA, USA) from the spleens and lymph nodes of CD40L ${ }^{-1-} \mathrm{B} 6$ mice. These $\mathrm{CD}^{+} \mathrm{T}$ cells $\left(2 \times 10^{6}\right.$ cells/mouse; $>97 \%$ purity $)$ were adoptively transferred into syngenic Rag- $1^{-1-}$ B6 mice. After undergoing HP for 6 weeks, $T_{\text {mem }}$ cells were phenotypically analyzed using flow cytometry with flurochrome-conjugated antibody staining; anti-CD44- 
fluorescein isothiocyanate (FITC) and anti-CD62L-phycoerythrin (PE) (eBiosciences, San Diego, CA, USA).

\section{Heterotopic Cardiac Transplantation}

Intra-abdominal heterotopic cardiac transplantation was performed as previously described [34]. In this study, surgery involved the transplantation of fully MHC-mismatched hearts from BALB/c donors $\left(\mathrm{H}-2^{\mathrm{d}}\right)$ to naïve $\mathrm{Rag}-1^{-/-} \mathrm{B} 6$ recipients $\left(\mathrm{H}-2^{\mathrm{b}}\right)$ or those harboring $\mathrm{T}_{\text {mem }}$ cells. The heartbeat of the grafts was monitored and evaluated daily by direct abdominal palpation in double-blind fashion to detect the state of cardiac health/rejection [34].

\section{Experimental Groups}

Three groups were included in this study: (1) Controls, naïve Rag-1 ${ }^{-/-}$B6 mice receiving cardiac allografts from BALB/c mice $(n=3)$; (2) Rag- $1^{-/-}$B6 mice harboring $\mathrm{T}_{\text {mem }}$ cells were transplanted with $\mathrm{BALB} / \mathrm{c}$ cardiac allografts without any treatment $(n=8)$; and (3) Rag- $1^{-/-}$B6 mice harboring $\mathrm{T}_{\text {mem }}$ cells were transplanted with BALB/c cardiac allografts, and were treated with rat anti-OX40L monoclonal antibody (mAb) (clone RM134L, rat IgG2b; BioXcell, West Lebanon, NH, USA) ( $0.5 \mathrm{mg} / \mathrm{mouse} /$ day, intraperitoneal injection) for 10 days (day $0-10)(n=8)$. Heart graft samples were collected and analyzed on postoperative day (POD) 100.

\section{Graft Histology}

Formaldehyde-fixed, paraffin-embedded tissue samples were sectioned at $4 \mu \mathrm{m}$, and stained with hematoxylin and eosin [35]. The sections were examined for severity of rejection, particularly CAV, by a pathologist in a blinded fashion [36]. Criteria for graft rejection included evidence of intimal thickening with luminal narrowing, fibrosis and cellular infiltration.

\section{Immunohistochemistry}

Cryosections embedded in Tissue-Tek O.C.T (Skura Finetek, Torrance, CA, USA), mounted on gelatin-coated slides were stained using an avidin-biotin immunoperoxidase method (Vector Laboratories, Burlingame, CA, USA) [34]. Intragraft T cell infiltration was detected using primary antibody anti-mouse CD4 (clone YTS 191.1.2; Cedarlane Laboratories Canada, Burlington, ON), and anti-mouse CD8 mAbs (clone 53-6.7: BD BiosciencesCanada, Mississauga, ON), while intragraft monocyte/macrophage infiltration was identified with an anti-Mac-1 mAb (clone M1/70; Cedarlane Laboratories Canada). Negative stain controls were those sections stained omitting the primary antibodies. Antibody reactivity was evaluated on five randomly selected high-powered bright-phase microscope fields of each tissue section obtained from eight animals per group.

\section{Determination of Cellular Phenotypic Expression}

Cell phenotypes were analyzed using a FACS Calibur flow cytometer (Becton Dickinson Canada Inc., Mississauga, ON). All FITC-, PE- and CyChrome (Cy)-conjugated goat or rat anti-mouse antibodies were purchased from BD Biosciences-Canada, Cedarlane Laboratories Canada, or $e$ Bioscience. All of flow cytometric analyses were compared to 
their appropriate control goat or rat Ig isotypes [34]. Phenotypic analysis of $\mathrm{T}_{\mathrm{mem}}$ cells involved triple flurochrome-conjugated antibody staining with anti-CD4 or -CD8-FITC, CD44-PE-Cy5 and -OX40-PE.

\section{Real-Time RT-PCR}

Quantitative analyses of transcript (mRNA) levels of tumor necrosis factor (TNF)-a, transforming growth factor (TGF) $\beta$ and Interferon (IFN)- $\gamma$ were performed by real-time RT-PCR. Briefly, total RNA was extracted from heart grafts with a spin column, according to the manufacturer's protocol (Qiagen Inc.-Canada, Toronto, ON). cDNA pools were synthesized with the First-Strand Synthesis System according to the manufacturer's protocol (Stratagene/Agilent Technologies, Santa Clara, CA, USA). Primers were designed using Primer Express, primer designing software from Applied Biosystems (Life TechnologiesInvitrogen, Burlington, ON): TNF-a: 5'-GGCTGCCCTGTCCTTCCTAGATA and 5'CGAGCTAG TGACACTCTGACACTCC; TGF- $\beta$ : $5^{\prime}$-TTGCTTCAGCTC CACAGAGA and 5'-TGGTTGTAGAGGGCAAGGAC; IFN- $\gamma$ : 5'-CGGCACAGTCATTGAAAGCCTA and 5'-GTTGCTGATGGCCTGATTGTC; $\beta$-actin: 5'-GATGACGATATCGCTGCGCTG and 5'-GTACGACCAGAGGCAT ACAGG. The gene sequences were obtained from the www.ncbi.nlm.nih.gov database. Real-time quantitative PCR was performed on standardized quantities of cDNA using the Brilliant SYBR Green QPCR Master Mix kit, and amplified DNA products were generated and detected using the Mx4000 system (Stratagene/Agilent Technologies). Each PCR amplification condition was set up in triplicate. $\beta$-actin amplification was used as an endogenous control. The normalized delta threshold cycle value and relative expression levels $\left(2^{-\Delta \Delta \mathrm{Ct}}\right)$ were calculated according to the manufacturer's protocol (Stratagene/Agilent Technologies).

\section{Statistical Analyses}

Histological and immunohistological findings were analyzed non-parametrically using ANOVA-on-rank Statistical comparisons of cytokine levels and cell phenotype differences were performed using Student's t-test. All these statistical analyses were performed using SigmaPlot computer software (Systat Software, Inc., San Jose, CA, USA). Differences with $p$ values $₫ .05$ were considered significant.

\section{Results}

\section{HP Generates CD40L Deficient $\mathrm{T}_{\text {mem }}$ Cells in Transplant Recipients}

It has been demonstrated that $\mathrm{T}_{\mathrm{mem}}$ cells can be generated from syngeneic naïve $\mathrm{T}$ cells in immunodeficient mice via HP $[28,37]$. To generate CD40L deficient $T_{\text {mem }}$ cells in transplant recipients, $\mathrm{CD}^{+} \mathrm{T}$ cells were isolated from the spleens and lymph nodes of

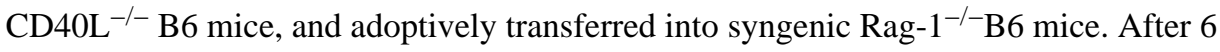
weeks of HP, the transferred T cells acquired high levels of CD44 (CD44high) and low expression of CD62L (CD62 ${ }^{\text {low }}$ ) (Fig. 1), a typical phenotype of $\mathrm{T}_{\text {mem }}$ cells [38] that was $86.13 \pm 5.22 \%$ of total splenocytes in these recipient Rag- $1^{-/-}$B6 mice $(n=3)$. This result confirmed that transferred $\mathrm{T}$ cells lost their naïvety, and acquired features of $\mathrm{T}_{\mathrm{mem}}$ cells in the Rag-1 deficient B6 mice. 
CD40L Deficient $T_{\text {mem }}$ Cells Induce CAV that is Prevented by Anti-OX40L mAb Treatment

In order to verify if $\mathrm{T}_{\text {mem }}$ cells could induce CAV development, and OX40 pathway blockade would be effective at preventing graft CAV, fully MHC mismatched BALB/c heart allografts were transplanted into Rag- $1^{-/}$B6 recipient mice harboring CD40L deficient $\mathrm{T}_{\text {mem }}$ cells (Group 2) compared to those without $\mathrm{T}$ cell transfer (Group 1). In addition, one half of recipient mice in Group 2 were randomly selected for anti-OX40L mAb treatment (Group 3) to determine the role of OX40 pathway blockade in the transplant outcomes. On POD 100 the cardiac allografts in naïve recipient Rag- $1^{-/-}$B6 mice (Group 1) showed normal histology — without CAV but the presence of mild cellular infiltration in perivascular area (Fig. 2a), whereas in recipients harboring $\mathrm{T}_{\text {mem }}$ cells (Group 2), six out of eight graft samples developed severe changes, one showing moderate intimal thickening - a typical pathological feature of CAV (Fig. 2b). Furthermore, treatment with anti-OX40L mAb (Group 3) resulted in complete prevention of CAV development in cardiac allografts, indicated by the lack of any pathological changes of CAV-intimal thickening in eight allografts from antibody-treated recipients on POD 100 (Fig. 2c), however, mild myocardial interstitial fibrosis was noticed in these grafts.

\section{Treatment with Anti-OX40L Decreases $\mathrm{T}_{\text {mem }}$ Cell Population in Transplant Recipients}

To confirm if anti-OX40L mAb therapy or OX40 pathway interference specifically impaired $\mathrm{T}_{\text {mem }}$ cell development in transplant recipients, the population of $\mathrm{T}_{\text {mem }}$ cells with OX40 expression in the splenocytes was measured in transplant recipients on POD 100. As expected, in untreated recipients (Group 2) there was a high proportion of $\mathrm{CD} 4^{+} \mathrm{OX} 40^{+} \mathrm{CD} 44^{\text {high }}$ or $\mathrm{CD} 8^{+} \mathrm{OX} 40^{+} \mathrm{CD} 44^{\text {high }} \mathrm{T}_{\text {mem }}$ cells (Fig. 3), while in those receiving anti-OX40L mAb treatment (Group 3), the number of both CD4 and CD8 $\mathrm{T}_{\text {mem }}$ cells was significantly reduced (Fig. $3, P<0.001$, Group 2 vs. $3, n=8$ ). These results suggest that the OX40 pathway plays a significant role in the generation of $\mathrm{T}_{\text {mem }}$ cells that mediate CAV development in cardiac allografts.

\section{Treatment with Anti-OX40L is Associated with a Reduction of Cellular Infiltration and Cytokine Expression in Cardiac Allografts on POD 100}

To further understand the mechanism by which treatment with anti-OX40L mAbs prevents CAV, the impact of anti-OX40L mAb therapy on cellular infiltration and cytokine expression in transplants was examined on POD 100. Immunohistochemistry data showed massive cellular infiltration of CD4, CD8, and Mac-1 positive cells in cardiac allografts from untreated recipient animals on POD 100 (Fig. 4a, c, e), whereas analysis of grafts from recipient animals treated with anti-OX40L mAb showed almost no cellular infiltration on the same day (Fig. 4b, d, f) in this limited number of samples.

The expression of the intragraft cytokine profile (TNF- $\alpha$, IFN- $\gamma$ and TGF- $\beta$ ) was also examined in these transplants. In untreated control grafts, there were high levels of TNF- $a$, IFN- $\gamma$ and TGF- $\beta$ on POD 100 (Fig. 5), however in grafts treated with anti-OX40L mAb therapy these cytokines were significantly reduced (Fig. 5, $P<0.01$, Group 2 vs. 3, $n=5$ ). Taken together, these results suggest that anti-OX40L mAb decreases not only the $\mathrm{T}_{\text {mem }}$ cell population in spleens but also cellular infiltration $\left(\mathrm{CD} 4^{+}\right.$and $\mathrm{CD} 8^{+} \mathrm{T}$ cells, and macrophages) and cytokine (TNF- $\alpha$, IFN- $\gamma$ and TGF- $\beta$ ) expression in transplants. 


\section{Discussion}

We believe that this experimental study demonstrates for the first time that CD40L deficient $\mathrm{T}_{\text {mem }}$ cells induce CAV in cardiac allografts, and blockage of the OX40 signaling pathway using anti-OX40L mAb reduces $\mathrm{T}_{\text {mem }}$ cell development and prevents CAV in a mouse cardiac transplantation model. Our findings are consistent with another similar study by Nakano et al. in a different animal model, where they reported that genetic deletion of OX40L suppresses the formation of atherosclerosis in mice [39]. Thus, we believe that the OX40 pathway can be used not only for immunosuppression as suggested in literature [18], but also for the prevention of CAV in cardiac transplant recipients.

To better understanding the role of $\mathrm{T}_{\mathrm{mem}}$ cells in $\mathrm{CAV}$, we developed a novel $\mathrm{T}_{\mathrm{mem}}$ cellmediated CAV model, in which two criteria are met: 1) $\mathrm{T}_{\text {mem }}$ cells are a major Tcell population in recipient mice and, 2) CAV develops in cardiac allografts. Rag- $1^{-/-} \mathrm{B} 6$ mice were chosen as recipients in this model because these mice do not produce mature $\mathrm{T}$ and $\mathrm{B}$ lymphocytes on their own [24], and $\mathrm{T}_{\text {mem }}$ cells can be generated in these mice by adoptive transfer of naïve T cells as reported previously [37, 40]. We have also found that although heart transplants from BALB/c mice in fully MHC class II-mismatched recipient $\mathrm{CD} 40 \mathrm{~L}^{-/-}$ B6 mice can survive for 100 days, they ultimately develop atherosclerosis or CAV[30], suggesting that $\mathrm{CD}_{40 \mathrm{~L}^{-/}}$alloreactive $\mathrm{T}$ cells do not induce acute allograft rejection, but can cause subacute immune-mediated vascular injury, resulting in CAV development in longterm survived grafts. Therefore, we felt that a $\mathrm{T}_{\text {mem }}$ cell-mediated CAV model could be established where $\mathrm{CD}^{+} \mathrm{T}$ cells from $\mathrm{CD} 40 \mathrm{~L}^{-/-} \mathrm{B} 6$ mice are adoptively transferred into Rag- $1^{-/-}$B6 mice to generate $T_{\text {mem }}$ cells in these recipient mice. After 6 weeks of HP, heart grafts from BALB/c mice were transplanted into the Rag- $1^{-/-}$B6 recipients to develop CAV. Indeed, after 6 weeks of adoptive transfer of naïve T cells into Rag-1 ${ }^{-/-}$B6 mice, more than $86 \%$ of splenocytes became $\mathrm{CD} 44^{\text {high }}{ }^{\mathrm{CD}} 62^{\text {low }} \mathrm{T}_{\text {mem }}$ cells (Fig. 1 ), and induced CAV in survived cardiac allografts in these recipients (Fig. 2). However, one has to acknowledge the limitations of this model: 1) although the majority of splenocytes are 'memory' type T cells, other immune effector cells, such as macrophages, NK cells and NKT cells, may contribute to the pathogenesis of CAV as well; 2) it is still unknown if $\mathrm{T}_{\text {mem }}$ cells generated by HP from naïve $\mathrm{T}$ cells are the same as seen in coronary arteries from patients with CAV.

It has been shown that in patients with $\mathrm{CAV}$, the activated $\mathrm{T}_{\text {mem }}$ cells in their coronary arteries are a major population of infiltrating mononuclear cells [8]. In addition, in vitro endothelial cells, but not vascular smooth muscle cells (VSMC), up-regulate OX40L expression in response to proinflammatory cytokines, which enhances $\mathrm{T}_{\text {mem }}$ cell responses to VSMC [41], and in vivo treatment with anti-OX40L mAb in animals receiving allotransplants inhibits $\mathrm{T}_{\text {mem }}$ cell expansion via apoptosis $[37,42]$ and IFN- $\gamma$ production of $\mathrm{CD} 4{ }^{+} \mathrm{T}_{\text {mem }}$ cells [37]. The present study further confirms these observations in our unique model; $\mathrm{CD} 4 \mathrm{~L}^{-/-} \mathrm{T}_{\mathrm{mem}}$ cells, generated by $\mathrm{HP}$, have the capacity to induce $\mathrm{CAV}$ in cardiac allografts (Fig. 2) and in vivo treatment with anti-OX40L mAb reduces the number of $\mathrm{T}_{\mathrm{mem}}$ cells in the spleens (Fig. 3) and infiltrating $\mathrm{CD} 4^{+}$and $\mathrm{CD} 8^{+} \mathrm{T}$ cells in grafts (Fig. 4), which correlates with the absence of CAVin cardiac allografts. All these studies may suggest that $\mathrm{T}_{\mathrm{mem}}$ cells that depend on OX40L-OX40 signaling are the pathogenic effector $\mathrm{T}$ cells for 
CAV in heart transplantation. We have to acknowledge that CAV in our model is mainly induced by the activation of CD40L $\mathrm{L}^{-/-} \mathrm{T}_{\mathrm{mem}}$ cells, and the efficacy of anti-OX40L mAb treatment against $\mathrm{CAV}$ is only demonstrated in the absence of other important leukocytes, such as T regulatory cells, which is also a limitation of this study.

It has been documented in literature that effector $\mathrm{T}_{\text {mem }}$ cells produce both IFN- $\gamma$ and TNF-a [43-46]. In the coronary arteries from heart transplant patients, IFN- $\gamma$-producing $\mathrm{T}_{\text {mem }}$ cells are only detected in CAV vessels, and these cells also express TGF- $\beta$ [9, 47]. The present study demonstrates similar results; higher levels of intragraft IFN- $\gamma$, TNF- $\gamma$ and TGF- $\beta$ are associated with infiltrating $\mathrm{T}_{\text {mem }}$ cells in grafts with CAV in untreated controls as compared to grafts without $\mathrm{CAV}$ in the anti-OX40L mAb treated group. To understand how these cytokines contribute to $\mathrm{T}_{\text {mem }}$ cell development and CAV, it is reported that IFN- $\gamma$ can directly stimulate VSMC proliferation via mTORC1 signaling [48-50]. TNF-a is a nonspecific inflammatory factor that can cause microvascular injury [51], and stimulates both $\mathrm{T}_{\text {mem }}$ cell development [52] and proliferation and migration of VSMC [53], while TGF- $\beta$ blocks activated-induced cell death in both primary and memory Th1 effectors, promoting $\mathrm{T}_{\text {mem }}$ cell survival [54].

In conclusion, the data from this study for the first time suggest that effector $\mathrm{T}_{\text {mem }}$ cells have the capacity of inducing CAV in cardiac allografts in an experimental model, and blocking the activation of OX40 receptors through neutralization with anti-OX40L mAb significantly reduces the recipient's ability to generate $\mathrm{T}_{\text {mem }}$ cells, either through initial generation and/or re-activation of pre-existing $T_{m e m}$ cells. The absence of $T_{\text {mem }}$ cells in the recipient results in the protection of the heart transplants from CAV development. Our study provides proof-ofconcept that targeting OX40-OX40L signaling in $\mathrm{T}_{\text {mem }}$ cells has potential for preventing $\mathrm{CAV}$ and prolonging heart transplant survival in patients.

\section{Acknowledgments}

The authors are grateful to Wei Ge for technical assistance, and Mr. Jeffrey Helm for editorial assistance.

\section{References}

1. Murphy L, Pinney SP. Clinical outcomes following heart transplantation. Mt Sinai J Med. 2012; 79(3):317-29. [PubMed: 22678856]

2. Taylor DO, Edwards LB, Boucek MM, Trulock EP, Aurora P, Christie J, et al. Registry of the International Society for Heart and Lung Transplantation: twenty-fourth official adult heart transplant report-2007. J Heart Lung Transplant. 2007; 26(8):769-81. [PubMed: 17692781]

3. Gaudin PB, Rayburn BK, Hutchins GM, Kasper EK, Baughman KL, Goodman SN, et al. Peritransplant injury to the myocardium associated with the development of accelerated arteriosclerosis in heart transplant recipients. Am J Surg Pathol. 1994; 18(4):338-46. [PubMed: 8141428]

4. Rahmani M, Cruz RP, Granville DJ, McManus BM. Allograft vasculopathy versus atherosclerosis. Circ Res. 2006; 99(8):801-15. [PubMed: 17038650]

5. Ramzy D, Rao V, Brahm J, Miriuka S, Delgado D, Ross HJ. Cardiac allograft vasculopathy: a review. Can J Surg. 2005; 48(4):319-27. [PubMed: 16149368]

6. Eisen H, Ross H. Optimizing the immunosuppressive regimen in heart transplantation. J Heart Lung Transplant. 2004; 23(5 Suppl):S207-13. [PubMed: 15093807] 
7. Kurtulus S, Tripathi P, Hildeman DA. Protecting and rescuing the effectors: roles of differentiation and survival in the control of memory T cell development. Front Immunol. 2012; 3:404. [PubMed: 23346085]

8. van Loosdregt J, van Oosterhout MF, Bruggink AH, van Wichen DF, van Kuik J, de Koning E, et al. The chemokine and chemokine receptor profile of infiltrating cells in the wall of arteries with cardiac allograft vasculopathy is indicative of a memory T-helper 1 response. Circulation. 2006; 114(15):1599-607. [PubMed: 17015796]

9. Hagemeijer MC, van Oosterhout MF, van Wichen DF, van Kuik J, Siera-de Koning E, Gmelig Meyling FH, et al. T cells in cardiac allograft vasculopathy are skewed to memory Th- 1 cells in the presence of a distinct Th-2 population. Am J Transplant. 2008; 8(5):1040-50. [PubMed: 18416740]

10. Brook MO, Wood KJ, Jones ND. The impact of memory T cells on rejection and the induction of tolerance. Transplantation. 2006; 82(1):1-9. [PubMed: 16861933]

11. Calderhead DM, Buhlmann JE, van den Eertwegh AJ, Claassen E, Noelle RJ, Fell HP. Cloning of mouse OX40: a T cell activation marker that may mediate T-B cell interactions. J Immunol. 1993; 151(10):5261-71. [PubMed: 8228223]

12. Godfrey WR, Fagnoni FF, Harara MA, Buck D, Engleman EG. Identification of a human OX-40 ligand, a costimulator of $\mathrm{CD} 4^{+} \mathrm{T}$ cells with homology to tumor necrosis factor. J Exp Med. 1994; 180(2):757-62. [PubMed: 7913952]

13. So T, Lee SW, Croft M. Immune regulation and control of regulatory T cells by OX40 and 4-1BB. Cytokine Growth Factor Rev. 2008; 19(3-4):253-62. [PubMed: 18508403]

14. Zaini J, Andarini S, Tahara M, Saijo Y, Ishii N, Kawakami K, et al. OX40 ligand expressed by DCs costimulates NKT and CD4 ${ }^{+}$Th cell antitumor immunity in mice. J Clin Invest. 2007; 117(11):3330-8. [PubMed: 17975668]

15. Zingoni A, Sornasse T, Cocks BG, Tanaka Y, Santoni A, Lanier LL. Cross-talk between activated human NK cells and CD4 ${ }^{+}$T cells via OX40-OX40 ligand interactions. J Immunol. 2004; 173(6): 3716-24. [PubMed: 15356117]

16. Baumann R, Yousefi S, Simon D, Russmann S, Mueller C, Simon HU. Functional expression of CD134 by neutrophils. Eur J Immunol. 2004; 34(8):2268-75. [PubMed: 15259024]

17. Stuber E, Strober W. The T cell B cell interaction via OX40-OX40L is necessary for the T celldependent humoral immune response. J Exp Med. 1996; 183(3):979-89. [PubMed: 8642301]

18. Croft M. Control of immunity by the TNFR-related molecule OX40 (CD134). Annu Rev Immunol. 2010; 28:57-78. [PubMed: 20307208]

19. Gramaglia I, Jember A, Pippig SD, Weinberg AD, Killeen N, Croft M. The OX40 costimulatory receptor determines the development of CD4 memory by regulating primary clonal expansion. J Immunol. 2000; 165(6):3043-50. [PubMed: 10975814]

20. Croft M, So T, Duan W, Soroosh P. The significance of OX40 and OX40L to T-cell biology and immune disease. Immunol Rev. 2009; 229(1):173-91. [PubMed: 19426222]

21. Ishii N, Takahashi T, Soroosh P, Sugamura K. OX40-OX40 ligand interaction in T-cell-mediated immunity and immunopathology. Adv Immunol. 2010; 105:63-98. [PubMed: 20510730]

22. Salek-Ardakani S, Croft M. Regulation of CD4 T cell memory by OX40 (CD134). Vaccine. 2006; 24(7):872-83. [PubMed: 16176850]

23. Soroosh P, Ine S, Sugamura K, Ishii N. Differential requirements for OX40 signals on generation of effector and central memory CD4 ${ }^{+}$T cells. J Immunol. 2007; 179(8):5014-23. [PubMed: 17911586]

24. Mombaerts P, Iacomini J, Johnson RS, Herrup K, Tonegawa S, Papaioannou VE. RAG-1-deficient mice have no mature B and T lymphocytes. Cell. 1992; 68(5):869-77. [PubMed: 1547488]

25. Pearl JP, Parris J, Hale DA, Hoffmann SC, Bernstein WB, McCoy KL, et al. Immunocompetent Tcells with a memory-like phenotype are the dominant cell type following antibody-mediated T-cell depletion. Am J Transplant. 2005; 5(3):465-74. [PubMed: 15707400]

26. Valujskikh A, Lakkis FG. In remembrance of things past: memory T cells and transplant rejection. Immunol Rev. 2003; 196:65-74. [PubMed: 14617198]

27. Tan JT, Ernst B, Kieper WC, LeRoy E, Sprent J, Surh CD. Interleukin (IL)-15 and IL-7 jointly regulate homeostatic proliferation of memory phenotype $\mathrm{CD} 8^{+}$cells but are not required for memory phenotype CD4 ${ }^{+}$cells. J Exp Med. 2002; 195(12):1523-32. [PubMed: 12070280] 
28. Goldrath AW, Bogatzki LY, Bevan MJ. Naive T cells transiently acquire a memory-like phenotype during homeostasis-driven proliferation. J Exp Med. 2000; 192(4):557-64. [PubMed: 10952725]

29. Murali-Krishna K, Ahmed R. Cutting edge: naive T cells masquerading as memory cells. J Immunol. 2000; 165(4):1733-7. [PubMed: 10925249]

30. Shimizu K, Schonbeck U, Mach F, Libby P, Mitchell RN. Host CD40 ligand deficiency induces long-term allograft survival and donor-specific tolerance in mouse cardiac transplantation but does not prevent graft arteriosclerosis. J Immunol. 2000; 165(6):3506-18. [PubMed: 10975872]

31. Wu Z, Wang Y, Gao F, Shen X, Zhai Y, Kupiec-Weglinski JW. Critical role of CD4 help in CD154 blockade-resistant memory CD8 T cell activation and allograft rejection in sensitized recipients. J Immunol. 2008; 181(2):1096-102. [PubMed: 18606661]

32. Zhai Y, Meng L, Gao F, Busuttil RW, Kupiec-Weglinski JW. Allograft rejection by primed/ memory $\mathrm{CD}^{+} \mathrm{T}$ cells is CD154 blockade resistant: therapeutic implications for sensitized transplant recipients. J Immunol. 2002; 169(8):4667-73. [PubMed: 12370407]

33. Olfert, ED.; Cross, BM.; McWilliam, AA. Responsibility for the care and use of experimental animals.. In: Olfert, ED.; Cross, BM.; McWilliam, AA., editors. Guide to the care and use of experimental animals (Vol 1). Association of Universities and Colleges of Canada; Ottawa: 1993. p. 1-14.

34. Wang H, Arp J, Liu W, Faas SJ, Jiang J, Gies DR, et al. Inhibition of terminal complement components in presensitized transplant recipients prevents antibody-mediated rejection leading to long-term graft survival and accommodation. J Immunol. 2007; 179(7):4451-63. [PubMed: 17878341]

35. Wang H, Hosiawa KA, Min W, Yang J, Zhang X, Garcia B, et al. Cytokines regulate the pattern of rejection and susceptibility to cyclosporine therapy in different mouse recipient strains after cardiac allografting. J Immunol. 2003; 171(7):3823-36. [PubMed: 14500684]

36. Racusen LC, Halloran PF, Solez K. Banff 2003 meeting report: new diagnostic insights and standards. Am J Transplant. 2004; 4(10):1562-6. [PubMed: 15367210]

37. Vu MD, Clarkson MR, Yagita H, Turka LA, Sayegh MH, Li XC. Critical, but conditional, role of OX40 in memory T cell-mediated rejection. J Immunol. 2006; 176(3):1394-401. [PubMed: 16424166]

38. Gerberick GF, Cruse LW, Miller CM, Sikorski EE, Ridder GM. Selective modulation of T cell memory markers CD62L and CD44 on murine draining lymph node cells following allergen and irritant treatment. Toxicol Appl Pharmacol. 1997; 146(1):1-10. [PubMed: 9299591]

39. Nakano M, Fukumoto Y, Satoh K, Ito Y, Kagaya Y, Ishii N, et al. Genetic Deletion of Ox40 Ligand Suppresses the Development of Atherosclerosis in Apolipoprotein E-Deficient Mice. J Vasc Res. 2009; 46:100.

40. Schuler T, Hammerling GJ, Arnold B. Cutting edge: IL-7-dependent homeostatic proliferation of $\mathrm{CD}^{+} \mathrm{T}$ cells in neonatal mice allows the generation of long-lived natural memory $\mathrm{T}$ cells. $\mathrm{J}$ Immunol. 2004; 172(1):15-9. [PubMed: 14688303]

41. Zhang P, Manes TD, Pober JS, Tellides G. Human vascular smooth muscle cells lack essential costimulatory molecules to activate allogeneic memory T cells. Arterioscler Thromb Vasc Biol. 2010; 30(9):1795-801. [PubMed: 20539019]

42. Ge W, Jiang J, Liu W, Lian D, Saito A, Garcia B, et al. Regulatory T cells are critical to tolerance induction in presensitized mouse transplant recipients through targeting memory T cells. Am J Transplant. 2010; 10(8):1760-73. [PubMed: 20636455]

43. Hamann D, Baars PA, Rep MH, Hooibrink B, Kerkhof-Garde SR, Klein MR, et al. Phenotypic and functional separation of memory and effector human $\mathrm{CD}^{+}{ }^{+}$T cells. J Exp Med. 1997; 186(9): 1407-18. [PubMed: 9348298]

44. Lalvani A, Brookes R, Hambleton S, Britton WJ, Hill AV, McMichael AJ. Rapid effector function in CD8 ${ }^{+}$memory T cells. J Exp Med. 1997; 186(6):859-65. [PubMed: 9294140]

45. Zimmermann C, Prevost-Blondel A, Blaser C, Pircher H. Kinetics of the response of naive and memory CD8 Tcells to antigen: similarities and differences. Eur J Immunol. 1999; 29(1):284-90. [PubMed: 9933110]

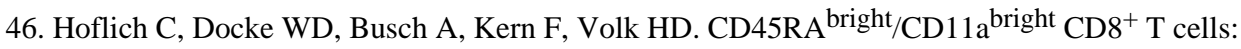
effector T cells. Int Immunol. 1998; 10(12):1837-45. [PubMed: 9885904] 
47. Huibers M, De Jonge N, Van Kuik J, Koning ES, Van Wichen D, Dullens H, et al. Intimal fibrosis in human cardiac allograft vasculopathy. Transpl Immunol. 2011; 25(2-3):124-32. [PubMed: 21782945]

48. Wang Y, Bai Y, Qin L, Zhang P, Yi T, Teesdale SA, et al. Interferon-gamma induces human vascular smooth muscle cell proliferation and intimal expansion by phosphatidylinositol 3-kinase dependent mammalian target of rapamycin raptor complex 1 activation. Circ Res. 2007; 101(6): 560-9. [PubMed: 17656678]

49. Tellides G, Pober JS. Interferon-gamma axis in graft arteriosclerosis. Circ Res. 2007; 100(5):62232. [PubMed: 17363708]

50. Tellides G, Tereb DA, Kirkiles-Smith NC, Kim RW, Wilson JH, Schechner JS, et al. Interferongamma elicits arteriosclerosis in the absence of leukocytes. Nature. 2000; 403(6766):207-11. [PubMed: 10646607]

51. Kirkiles-Smith NC, Tereb DA, Kim RW, McNiff JM, Schechner JS, Lorber MI, et al. Human TNF can induce nonspecific inflammatory and human immune-mediated microvascular injury of pig skin xenografts in immunodeficient mouse hosts. J Immunol. 2000; 164(12):6601-9. [PubMed: 10843720]

52. Shi M, Ye Z, Umeshappa KS, Moyana T, Xiang J. Alpha tumor necrosis factor contributes to $\mathrm{CD}^{+} \mathrm{T}$ cell survival in the transition phase. Biochem Biophys Res Commun. 2007; 360(3):702-7. [PubMed: 17618911]

53. Davis R, Pillai S, Lawrence N, Sebti S, Chellappan SP. TNF-alpha-mediated proliferation of vascular smooth muscle cells involves Raf-1-mediated inactivation of Rb and transcription of E2F1-regulated genes. Cell Cycle. 2012; 11(1):109-18. [PubMed: 22185776]

54. Carter LL, Zhang X, Dubey C, Rogers P, Tsui L, Swain SL. Regulation of T cell subsets from naive to memory. J Immunother. 1998; 21(3):181-7. [PubMed: 9610909] 


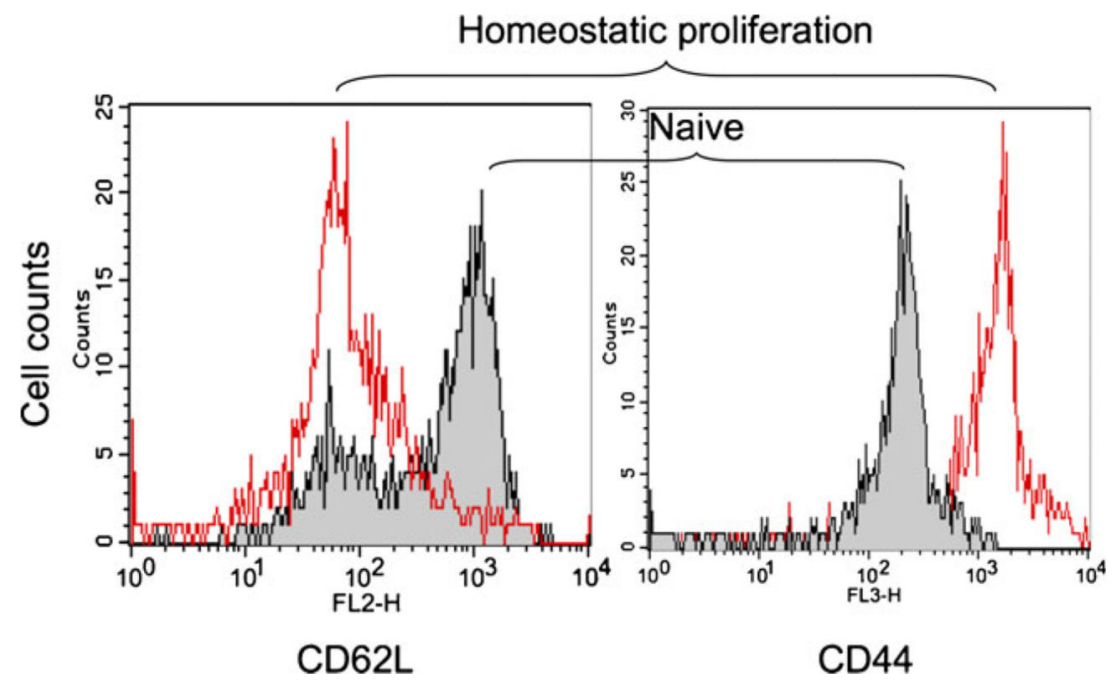

Fig. 1.

Phenotypic analysis of $\mathrm{CD}_{40 \mathrm{~L}^{-1-}} \mathrm{B} 6$ mouse naive and $\mathrm{T}_{\text {mem }}$ cells. Naive $\mathrm{CD}^{+} \mathrm{T}$ cells from CD40L $\mathrm{L}^{-/-}$B6 mice were adoptively transferred into Rag-1 deficient B6 mice, and allowed to undergo homeostatic proliferation for 6 weeks. The phenotypes of both cell types were determined using a flow cytometry with flurochrome-conjugate antibody staining with antiCD44-FITC and anti-CD62L-PE. Data are a representative of three mice 

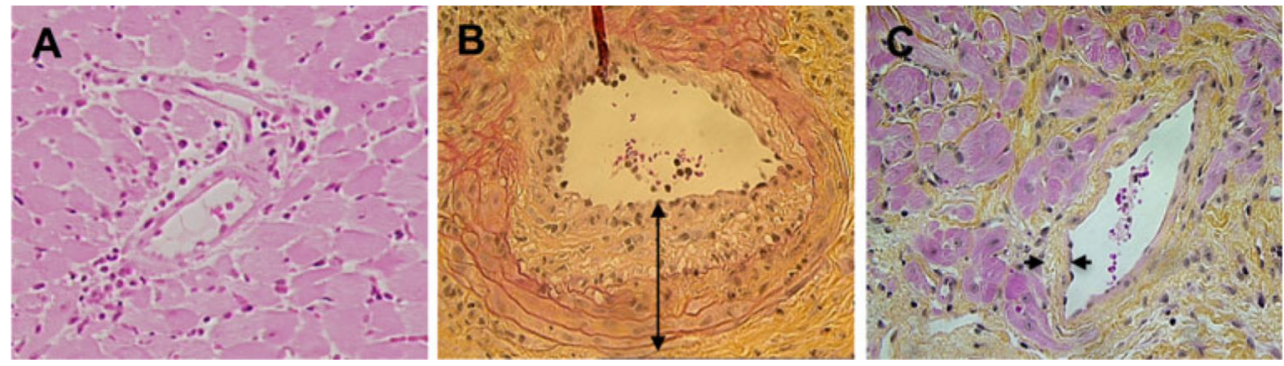

Fig. 2.

CAV development in cardiac allografts in Rag-1 deficient recipients. BALB/c mouse heart allografts in Rag-1 $1^{-/-}$B6 mouse recipients were harvested on POD 100. CAV was evaluated in H\&E stained paraffin sections. Data are presented as a typical image of vascular lesion in the arteries. a Heart grafts from naïve Rag-1 $1^{-/-}$recipients-lack of $\mathrm{T}_{\text {mem }}$ cells (Group $1, n$ =3). b Heart grafts from Rag-1 ${ }^{-/-}$recipients harboring $\mathrm{T}_{\text {mem }}$ cells (Group 2, $n=8$ ), showing severe CAV. c Heart grafts from Rag- $1^{-/-}$recipients harboring $\mathrm{T}_{\text {mem }}$ cells and receiving anti-OX40L mAb treatment (Group 3, $n=8$ ) 
A

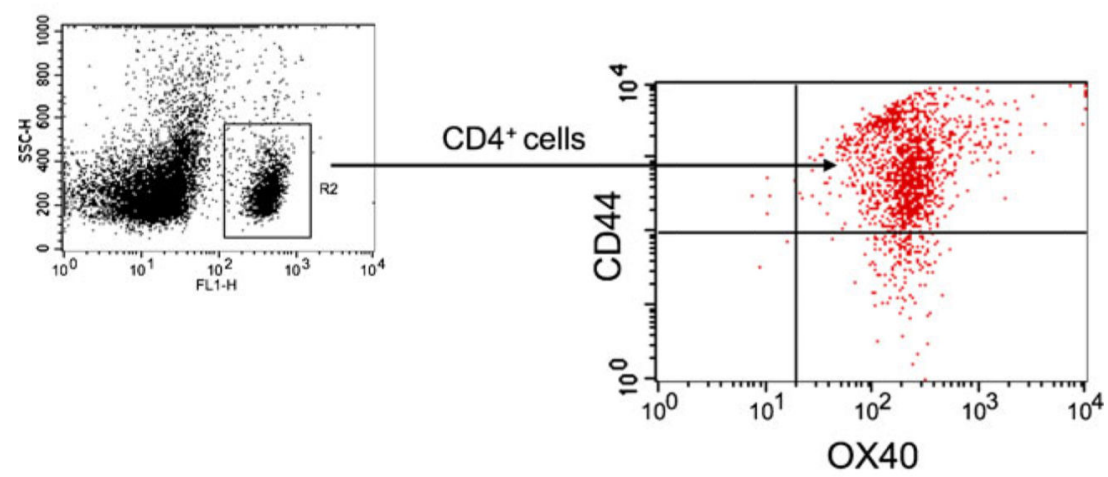

B

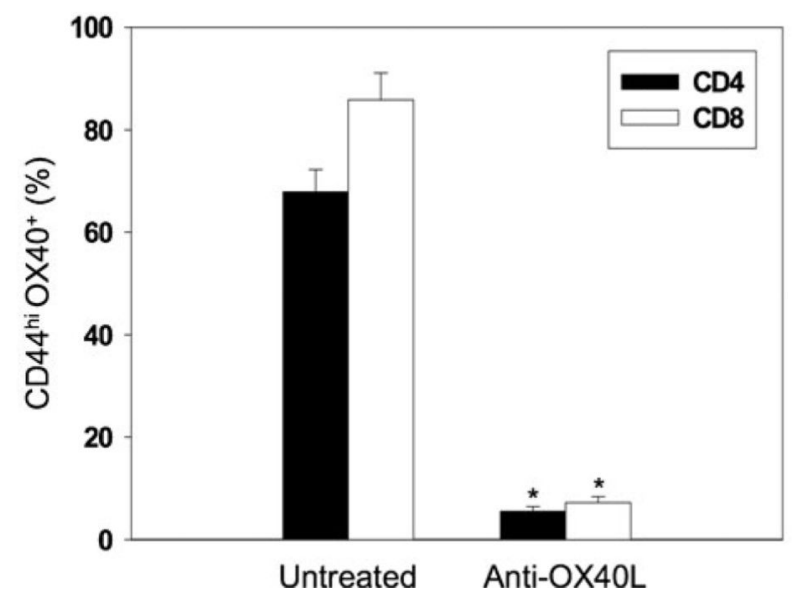

Fig. 3.

Regulation of $\mathrm{CD}^{+} \mathrm{OX} 40^{+} \mathrm{CD} 44^{\mathrm{hi}}$ and $\mathrm{CD} 8^{+} \mathrm{OX} 40^{+} \mathrm{CD} 44^{\text {hi }} \mathrm{T}$ cells by anti-OX40L mAb treatment in allograft recipients. The splenocytes were harvested from the recipient mice on POD 100. a Representative dot plots of OX40 and CD44 staining of CD4 ${ }^{+}$cells. b Frequency of $\mathrm{CD} 4{ }^{+} \mathrm{OX} 40^{+} \mathrm{CD} 44^{\mathrm{hi}}$ and $\mathrm{CD} 8^{+} \mathrm{OX} 40^{+} \mathrm{CD} 44^{\text {hi }} \mathrm{T}$ cells were analyzed by flow cytometric analysis, and expressed graphically in terms of mean percentages $( \pm \mathrm{SEM})$ that were statistically compared using Student's $t$-test test $\left({ }^{*} P<0.001\right.$, vs. untreated, $\left.n=8\right)$ 

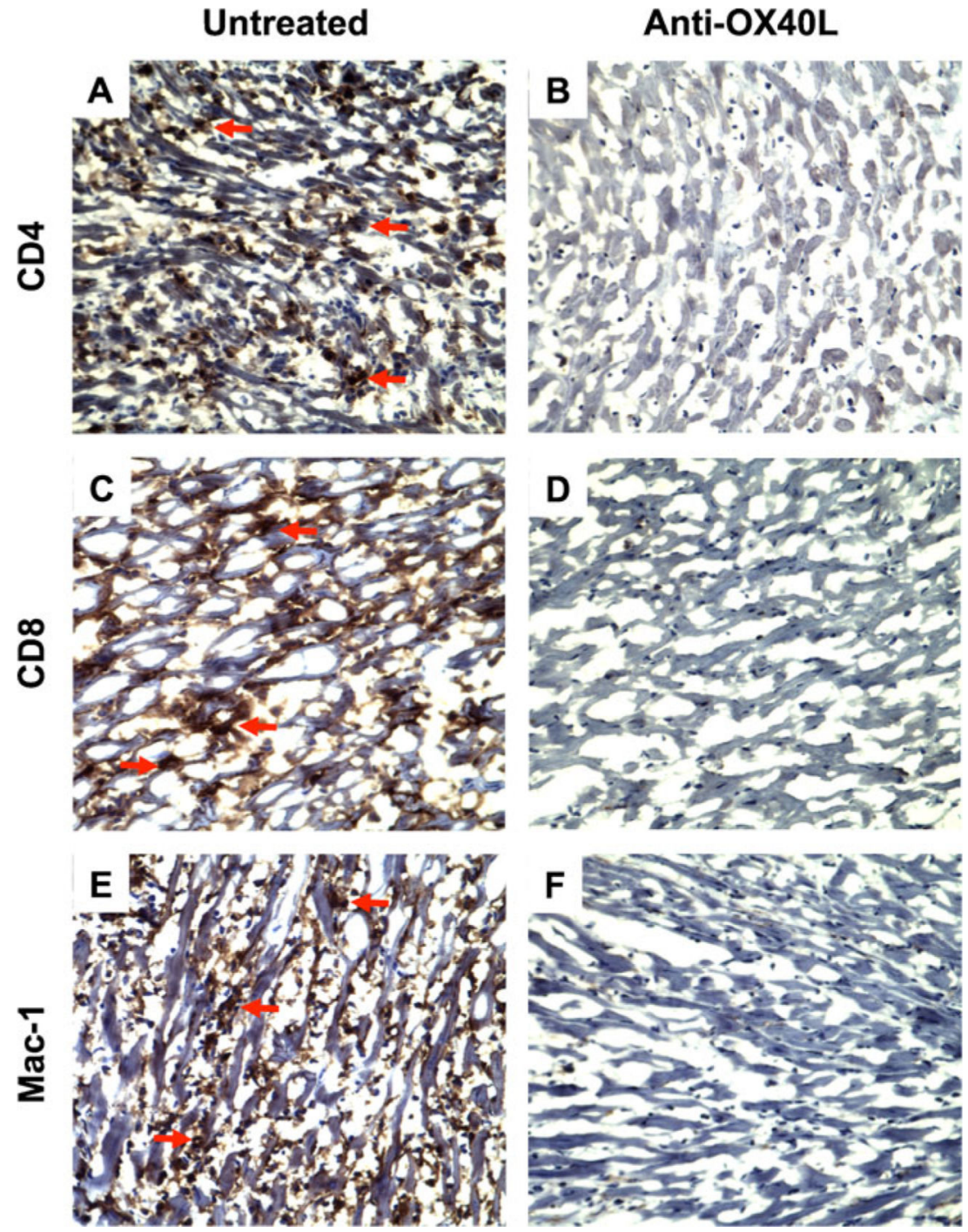

Fig. 4.

Regulation of cellular infiltration (CD4 and CD8 Tcells, and macrophages) in heart allogarfts by anti-OX40L mAb treatment. Cardiac allografts in Rag-1 ${ }^{-/-} \mathrm{B} 6$ recipients were harvested on POD 100. The CD4, CD8 and Mac-1 expressing cells in the sections of the grafts were localized by immunohistochemistry. Data are presented as a representative immunoperoxidase staining for each of $\mathrm{CD}^{+}, \mathrm{CD} 8^{+}$, and Mac- $1^{+}$cells. a, $\mathbf{c}$ and $\mathbf{e}$ A typical microscopic view of $\mathrm{CD} 4^{+} \mathrm{T}$ cells, $\mathrm{CD} 8^{+} \mathrm{T}$ cells, or Mac- $1^{+} /$macrophages in the sections of the grafts from Rag- $1^{-/-}$recipients harboring $\mathrm{T}_{\text {mem }}$ cells (Group 2, untreated, $n=8$ ). The red arrows indicated positively stained (brown) cells. $b, d$ and $f$ A typical microscopic view of $\mathrm{CD} 4, \mathrm{CD} 8$, or Mac-1 staining in the sections of the grafts from Rag- $1^{-1-}$ recipients harboring $\mathrm{T}_{\mathrm{mem}}$ cells and receiving anti-OX40L mAb treatment (Group 3, $\left.n=8\right)$. Cytoplasm: blue. Nucleus: dark blue 


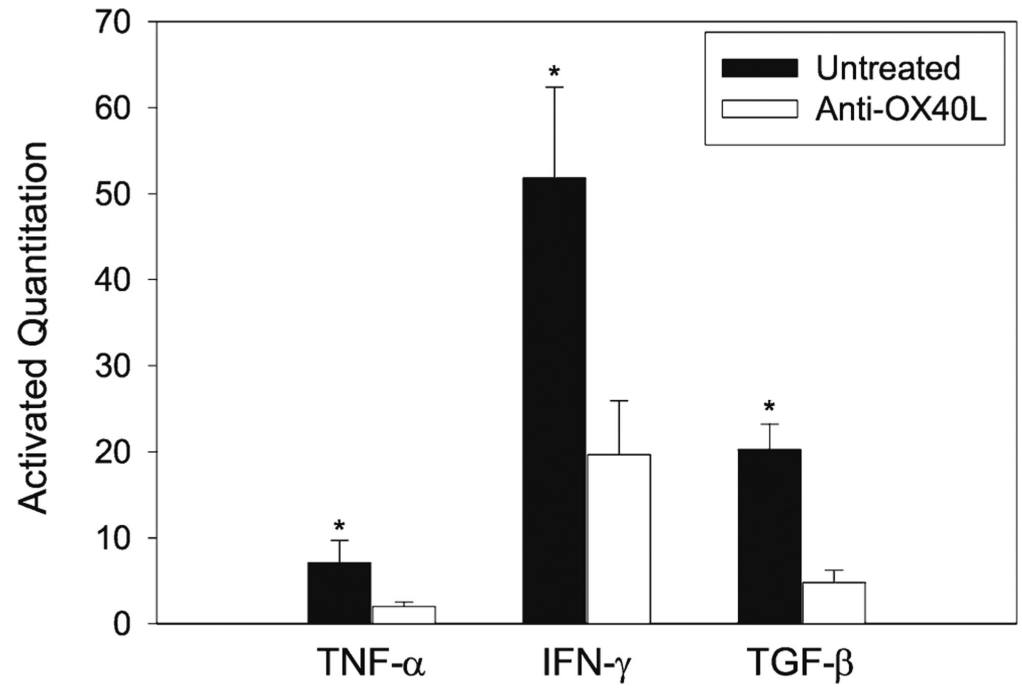

Fig. 5.

Attenuation of cytokine expression in cardiac allografts by anti-OX40L mAb treatment. Cardiac allografts in Rag-1 ${ }^{-/-}$B6 recipients were harvested on POD 100. Five tissues from each group were randomly selected for total RNA extraction. The intragraft expression of TNF- $\alpha$, IFN- $\gamma$, TGF- $\beta$ in the grafts in untreated versus anti-OX40L mAb-treated groups was analyzed by real-time RT-PCR. Data are presented as mean percentages $( \pm$ SEM) that were statistically compared using Student's $t$-test test ( $* P<0.05$ vs. untreated controls, $n=5$ ) 